\title{
Nursing care mapping for patients at risk of falls in the Nursing Interventions Classification*
}

\author{
MAPEAMENTO DE CUIDADOS DE ENFERMAGEM PARA PACIENTES COM RISCO DE QUEDAS \\ NA NURSING INTERVENTIONS CLASSIFICATION
}

\author{
MAPEO DE CUIDADOS DE ENFERMERÍA PARA PACIENTES CON RIESGO DE CAÍDAS EN LA \\ NURSING INTERVENTIONS CLASSIFICATION
}

Melissa de Freitas Luzia', Miriam de Abreu Almeida², Amália de Fátima Lucena ${ }^{3}$

\begin{abstract}
Objective: Identifying the prescribed nursing care for hospitalized patients at risk of falls and comparing them with the interventions of the Nursing Interventions Classifications (NIC). Method: A cross-sectional study carried out in a university hospital in southern Brazil. It was a retrospective data collection in the nursing records system. The sample consisted of 174 adult patients admitted to medical and surgical units with the Nursing Diagnosis of Risk for falls. The prescribed care were compared with the NIC interventions by the cross-mapping method. Results: The most prevalent care were the following: keeping the bed rails, guiding patients/family regarding the risks and prevention of falls, keeping the bell within reach of patients, and maintaining patients' belongings nearby, mapped in the interventions Environmental Management: safety and Fall Prevention. Conclusion: The treatment prescribed in clinical practice was corroborated by the NIC reference.
\end{abstract}

\section{RESUMO}

Objetivo: Identificar os cuidados de enfermagem prescritos para pacientes hospitalizados com risco de quedas e compará-los com as intervenções da Nursing Interventions Classifications (NIC). Método: Estudo transversal realizado em um hospital universitário do Sul do Brasil. A coleta de dados foi retrospectiva em sistema informatizado de registros de enfermagem. A amostra se constituiu de 174 pacientes adultos internados em unidades clínicas e cirúrgicas com o Diagnóstico de Enfermagem Risco de quedas. Os cuidados prescritos foram comparados com as intervenções da NIC pelo método de mapeamento cruzado. Resultados: Os cuidados mais prevalentes foram: manter grades no leito, orientar paciente/família quanto aos riscos e prevenção de quedas, manter campainha ao alcance do paciente e manter pertences próximos ao paciente, mapeadas nas intervenções Controle do Ambiente: Segurança e Prevenção contra Quedas. Conclusão: Os cuidados prescritos na prática clínica foram corroborados pelo referencial da NIC.

\section{RESUMEN}

Objetivo: Identificar los cuidados de enfermería prescritos para pacientes hospitalizados con riesgos de caídas y compararlos con las intervenciones de la Nursing Interventions Classifications (NIC). Método: Estudio transversal realizado en un hospital universitario del sur de Brasil. La recolección de datos fue retrospectiva en un sistema informatizado de registros de enfermería. La muestra se constituyó por 174 pacientes adultos internados en unidades clínicas y quirúrgicas con el Diagnóstico de Enfermería Riesgo de Caídas. Los cuidados prescritos fueron comparados con las intervenciones de la NIC por el método de mapeo cruzado. Resultados: Los cuidados más prevalentes fueron: mantener barandas en la cama, orientar al paciente y familia en relación a los riesgos y prevención de caídas, mantener el timbre al alcance del paciente y mantener las pertenencias cerca al paciente. Estos fueron mapeados en las intervenciones Control del Ambiente: Seguridad y Protección contra Caídas. Conclusión: Los cuidados prescritos en la práctica clínica fueron corroborados por el referencial de la NIC.

\author{
DESCRITORES \\ Diagnóstico de enfermagem \\ Cuidados de enfermagem \\ Acidentes por quedas \\ Pacientes internados \\ Hospitalização
}

\author{
DESCRIPTORES \\ Diagnóstico de enfermería \\ Cuidados de enfermería \\ Accidentes por caídas \\ Pacientes internos \\ Hospitalización
}

\footnotetext{
* Extracted from the thesis titled "Análise do Diagnóstico de Enfermagem Risco de quedas em pacientes adultos hospitalizados", Universidade Federal do Rio Grande do Sul, 2012. ${ }^{1}$ Master in Nursing from the School of Nursing, Federal University of Rio Grande do Sul, Porto Alegre, RS, Brazil. ${ }^{2}$ Associate Professor, School of Nursing, Federal University of Rio Grande do Sul, Porto Alegre, RS, Brazil. ${ }^{3}$ Adjunct Professor, School of Nursing, Federal University
} of Rio Grande do Sul, Porto Alegre, RS, Brazil.

$\begin{aligned} \text { Rev Esc Enferm USP } & \text { Received: } 11 / 21 / 2013 \\ \text { 2014; 48(4):632-40 } & \text { Approved: 06/17/2014 }\end{aligned}$




\section{INTRODUCTION}

Falls are one of the major adverse events in hospitals, accounting for two in every five episodes related to patient care ${ }^{(1)}$. The occurrence of injuries resultant from falls can vary from excoriations and contusions, to fractures and head traumas, and even death. Such damage can cause limitations and physical disability, increase the length of hospital stay, and the costs related to treatment with ethical and legal implications for the institution ${ }^{(2-3)}$. The repercussions of falls may also be psychological, especially in the elderly, expressed by the fear of falling, insecurity in walking, worsening of functional decline, depression and social isolation ${ }^{(4)}$.

Patient safety is a priority for the World Health Organization (WHO) that launched the World Alliance for Patient Safety in October 2004, aiming to raise awareness for the improvement of safety in health care ${ }^{(5)}$. Following this trend, in April 2013, the Ministry of Health and the Brazilian Health Surveillance Agency (ANVISA) created the National Patient Safety Program (Programa Nacional de Segurança do Paciente - PNSP) aiming to promote actions for patient safety in health services of the country ${ }^{(6)}$.

The prevention of falls is one of the six international safety goals set by the WHO and also represents one of the safety protocols of the PNSP. There is an apparent concern of nursing in this context, when searching for grants in order to carry out interventions that enable a safer, quality and harm-free care.

One of the strategies has been the use of the nursing process, a systematic and scientifically grounded method of work that guides the care and documentation of professional practice ${ }^{(7)}$, allowing the evaluation of patients and the identification of risk factors for falls. In this clinical situation, nurses can determine the Nursing Diagnosis (ND) Risk for falls ${ }^{(8)}$, aimed at preventing falls through interventions.

The ND Risk for falls of the NANDA International (NANDA-I) is defined as risk for increased susceptibility to falling that may cause physical harm. It is based on risk factors that contribute to increased vulnerability of patients to falls, and has been used as a guide for planning nursing actions preventive of this event ${ }^{(8)}$. The Nursing Interventions Classification (NIC) on its turn, has priority interventions for this ND in order to establish special precautions for patients at risk of injury due to falling ${ }^{(9)}$.

Several studies, mainly in the context of community, provide evidence that multifactorial interventions are capable of reducing the rate of falls and injuries resulting from the event ${ }^{(10-12)}$. However, there is a limited number of studies addressing the specific nursing interventions targeted to patients at risk of falling in Brazilian hospital settings $s^{(13-15)}$, and with the description of such interventions using a standardized classification system as the $\mathrm{NIC}^{(9)}$.
Hence, arose the need to exploit the knowledge of nursing interventions implemented for preventing falls in hospital settings. This study was developed for this reason, aiming to identify the prescribed nursing care for hospitalized patients with the ND Risk for falls and comparing it with the NIC interventions.

The purpose is to explain what nursing has prescribed in the clinical practice of a Brazilian hospital to prevent falls, in addition to making this prescription of care visible by using an international system called Nursing Intervention Classification (NIC).

\section{METHOD}

This is a cross-sectional study carried out in a university hospital located in southern Brazil, where the nursing process is computerized, the ND follows the NANDA-I terminology ${ }^{(8)}$ and nursing interventions are listed based on the literature, clinical practice and the $\mathrm{NIC}^{(9)}$.

The sample consisted of 174 patients, calculated based on a study previously carried out at the institution $^{(16)}$. The prevalence of the ND Risk for falls was estimated at $13 \%$, the confidence interval of $95 \%$ and a margin of error of 0.05 .

Inclusion criteria were adults hospitalized in clinical and surgical units of the hospital with the ND Risk for falls in 2011. Patients who had more than one hospitalization during the study period were excluded to avoid repeating data of the same patient.

A retrospective data collection was carried out in the nursing records information system. Data were organized in spreadsheets of the Excel for Windows, and the Statistical Package for the Social Sciences (SPSS) version 18.0 was used for statistical analysis.

The prescribed nursing care for patients were compared with interventions described in the NIC by the cross-mapping method ${ }^{(17-18)}$.

For reaching this end came the following steps: 1) selection of an NIC intervention for each prescribed nursing care for the ND Risk for falls, considering as a starting point the connection levels between the NANDA-I nursing diagnosis and the NIC interventions (priority, suggested and optional additional); 2) selection of the NIC intervention based on the similarity between the prescribed care and the definition of intervention and its activities; 3) grouping of the prescribed nursing care according to the NIC intervention.

The authors signed a term of commitment for use of data, pledging to use information solely for research purposes, respecting the principles of confidentiality and anonymity. The study was approved by the Committee of Ethics and Research in Health of the institution under Protocol number 110631. 


\section{RESULTS}

Prescriptions for 174 patients with ND of Risk for falls were analyzed, with 48 different types in total. The number of prescribed treatments per patient was $4.8 \pm 3$ on average (Table 1).
The mapping of 48 different nursing care based on the similarity between the prescribed item and the definition of the NIC intervention and its respective activities allowed identifying 13 different interventions of this taxonomy, on the three different levels of connection between the NIC and the NANDA-I ${ }^{(9)}$.

Table 1 - Nursing care prescribed for patients with ND Risk for falls - Porto Alegre, 2012

\begin{tabular}{|c|c|c|}
\hline Nursing Care & $\mathbf{N}$ & $(\%)$ \\
\hline Keeping the bed rails & 145 & 83.3 \\
\hline Guiding patients/family regarding the risks and prevention of falls & 86 & 49.4 \\
\hline Keeping the bell within reach of patients & 71 & 40.8 \\
\hline Keeping patient's belongings nearby & 56 & 32.2 \\
\hline Taking vital signs & 52 & 29.8 \\
\hline Assisting in the shower & 41 & 23.5 \\
\hline Sensory assessment & 40 & 22.9 \\
\hline Keeping company during ambulation & 36 & 20.6 \\
\hline Sensory monitoring & 33 & 18.9 \\
\hline Reporting altered level of consciousness & 33 & 18.9 \\
\hline Care implementation with mechanical restraint & 32 & 18.4 \\
\hline Assisting patients in sitting on the chair & 27 & 15.5 \\
\hline Evaluating altered level of consciousness & 25 & 14.3 \\
\hline Maintaining constant vigilance & 24 & 13.7 \\
\hline Assisting in ambulation & 22 & 12.6 \\
\hline Assisting patients in using the bathroom & 19 & 10.9 \\
\hline Reporting signs of pain & 17 & 9.7 \\
\hline Performing bed bath & 15 & 8.6 \\
\hline Inspecting skin in search for hyperemic or ischemic points & 14 & 8.0 \\
\hline Sitting patients on the chair & 14 & 8.0 \\
\hline Making sure that patients/family understood the guidance & 14 & 8.0 \\
\hline Hygiene of the scalp & 11 & 6.3 \\
\hline Assisting in changing clothes & 10 & 5.7 \\
\hline Implementing care of facial hair removal & 9 & 5.1 \\
\hline Guiding patients/family & 9 & 5.1 \\
\hline Teaching the proper use of crutches, walker, cane, prosthesis & 9 & 5.1 \\
\hline Assessing pain using the intensity scale & 9 & 5.1 \\
\hline Removing from the environment objects that may offer risks to patients & 8 & 4.5 \\
\hline Monitoring patients during their mobilization & 8 & 4.5 \\
\hline Performing perineal hygiene after each bowel movement & 8 & 4.5 \\
\hline Reporting complaints of visual changes & 7 & 4.0 \\
\hline Stimulating hygiene care & 7 & 4.0 \\
\hline Observing signs of sedation, slowness & 5 & 2.8 \\
\hline Guiding on ways to adapt to one's limitations & 5 & 2.8 \\
\hline Assisting in feeding & 5 & 2.8 \\
\hline Taking patients to the shower & 4 & 2.3 \\
\hline Assisting in active movements & 3 & 1.7 \\
\hline Offering a wheelchair & 3 & 1.7 \\
\hline Performing body hygiene in the shower & 3 & 1.7 \\
\hline Communicating changes in blood pressure & 3 & 1.7 \\
\hline Assessing pain intensity & 3 & 1.7 \\
\hline Administering analgesia after evaluation & 3 & 1.7 \\
\hline Offering a mobile intravenous drip stand & 2 & 1.1 \\
\hline Evaluating the efficacy of analgesia & 2 & 1.1 \\
\hline Communicating changes during analgesia infusion & 2 & 1.1 \\
\hline Guiding the patients & 1 & 0.5 \\
\hline Explaining the responsibilities for patients/family & 1 & 0.5 \\
\hline Monitoring patient response to medication & 1 & 0.5 \\
\hline
\end{tabular}


Nursing care and its related correspondence with the priority interventions suggested by the NIC for the resolu- tion or improvement of the ND Risk for falls are described in Chart 1.

Chart 1 - Nursing care actions grouped according to priority interventions suggested by the NIC for the ND Risk for Falls - Porto Alegre, 2012

\begin{tabular}{|c|c|c|}
\hline Type of care mapped & NIC intervention & $\begin{array}{c}\text { Level of connection } \\
\text { NIC and ND }\end{array}$ \\
\hline $\begin{array}{l}\text { - Keeping the bed rails } \\
\text { - Keeping the bell within reach of patients* } \\
\text { - Keeping patients' belongings nearby } \\
\text { - Removing from the environment objects that may offer risks to patients* }\end{array}$ & Environmental Management: Safety & Priority \\
\hline $\begin{array}{l}\text { - Guiding patients/family regarding the risks and prevention of falls } \\
\text { - Making sure that patients/family understood the guidance } \\
\text { - Guiding patient/family } \\
\text { - Teaching the proper use of crutches, walker, cane, prosthesis } \\
\text { - Guiding the patients } \\
\text { - Guiding on ways to adapt to one's limitations } \\
\text { - Explaining the responsibilities for patients/family } \\
\text { - Assisting in ambulation } \\
\text { - Keeping company during ambulation } \\
\text { - Offering a wheelchair } \\
\text { - Monitoring patients during their mobilization } \\
\text { - Assisting in active movements }\end{array}$ & Fall Prevention & Priority \\
\hline $\begin{array}{l}\text { - Taking vital signs }{ }^{\S} \\
\text { - Communicating changes in blood pressure }\end{array}$ & Vital Signs Monitoring & Suggested \\
\hline $\begin{array}{l}\text { - Assisting patients in sitting on the chair* } \\
\text { - Sitting patients on the chair } \\
\text { - Offering a mobile intravenous drip stand }\end{array}$ & Self-Care Assistance: transfer & Suggested \\
\hline - Assisting patients in using the bathroom & Self-Care Assistance: Using the toilet & Suggested \\
\hline
\end{tabular}

* This care is also included in the intervention Fall Prevention.

$\S$ This care is also included in the intervention Surveillance.

Below are described the nursing care and the respec- ventions and those without connection with the ND Risk tive correspondence with the optional additional inter- for Falls, according to the NIC ${ }^{(9)}$ (Chart 2).

Chart 2 - Nursing care grouped according with the optional additional interventions and those without connection between the NIC and the ND Risk for falls - Porto Alegre, 2012

\begin{tabular}{|c|c|c|}
\hline Type of care & NIC intervention & $\begin{array}{l}\text { Level of connection } \\
\text { NIC and ND }\end{array}$ \\
\hline $\begin{array}{l}\text { - Assessing pain intensity } \\
\text { - Administering analgesia after evaluation } \\
\text { - Reporting signs of pain } \\
\text { - Evaluating the efficacy of analgesia } \\
\text { - Monitoring patient response to medication* } \\
\text { - Communicating changes during analgesia infusion* } \\
\text { - Assessing pain using the intensity scale }\end{array}$ & Pain Management & Optional aditional \\
\hline - Maintaining constant vigilance & Surveillance & Optional aditional \\
\hline $\begin{array}{l}\text { - Sensory assessment*§} \\
\text { - Sensory monitoring*§} \\
\text { - Reporting altered level of consciousness*§ } \\
\text { - Evaluating altered level of consciousness } * \S \\
\text { - Reporting complaints of visual changes* } \\
\text { - Observing signs of sedation, slowness* }\end{array}$ & Neurological monitoring & Unconnected \\
\hline $\begin{array}{l}\text { - Assisting in the shower } \\
\text { - Performing body hygiene in the shower } \\
\text { - Performing bed bath }\end{array}$ & Bathing & Unconnected \\
\hline
\end{tabular}


Continuation...

\begin{tabular}{|l|c|c|}
\hline Type of care & NIC intervention & $\begin{array}{c}\text { Level of connection } \\
\text { NIC and ND }\end{array}$ \\
\hline - Taking patients to the shower & & \\
- Hygiene of the scalp & & Bathing \\
- Performing perineal hygiene after each bowel movement & & Unconnected \\
- Implementing care of facial hair removal & & \\
\hline - Inspecting skin in search for hyperemic or ischemic points & & Unconnected \\
\hline - Care implementation with mechanical restraint & Physical restraint & Unconnected \\
\hline - Assisting in changing clothes & Self-Care Assistance: dressing/grooming & Unconnected \\
\hline - Stimulating hygiene care & Self-Care Assistance: bathing/hygiene & Unconnected \\
\hline - Assisting in feeding & Self-Care Assistance: feeding & . \\
\hline
\end{tabular}

* This care is also included in the intervention Fall Prevention.

$\S$ This care is also included in the intervention Surveillance.

\section{DISCUSSION}

This study identified the prescribed nursing care for prevention of falls in the hospital clinical practice mapped with the NIC. The most relevant interventions for patients with the ND Risk for falls, considering number of prescriptions and the number of different care found were: Environmental Management: Safety and Fall Prevention.

Among the 48 types of prescribed care, 42 were related to factors intrinsic to patients. However, the nursing care of keeping the bed rails, which is related to an environmental condition, had the highest number of prescriptions by nurses.

The Environmental Management: Safety intervention, defined as monitoring and manipulation of the physical environment to promote safety ${ }^{(9)}$ included mapping the most frequently prescribed nursing care actions (keeping the bed rails, keeping the bell and belongings close to patients and removing from the environment any object that may offer risks). These care actions are important in preventing falls among hospitalized patients, especially the elderly and patients with physical or cognitive limitations ${ }^{(3)}$.

Somewhat different findings were demonstrated in a study that identified the most frequently used nursing interventions for three groups of hospitalized elderly patients, in which the intervention Surveillance was the most frequently prescribed for those with risk for falls ${ }^{(14)}$. In the present study, the intervention Surveillance was used less frequently, showing that nursing care vary in different institutional contexts and are directed to the specific problems and characteristics of patients. This intervention included mapping the care action of maintaining constant vigilance, in addition to other actions of care that could also be mapped in more specific interventions, such as taking vital signs, reporting changes in blood pressure (Vital Signs Monitoring) and sensory assessing and monitoring, evaluating and reporting altered levels of consciousness (Neurological monitoring). However, it is noteworthy that patient safety is directly related to supervision. This intervention is recommended for preventing falls in hospitalized patients according to the PNSP guidelines that suggest the periodic monitoring to evaluate the comfort and safety of patients, and the development of mechanisms to supervise those using medications that increase the risk of falls ${ }^{(19)}$.

The condition of hospitalization is knowingly related to increased risk for falls not only by the presence of acute illness, comorbidities and treatments, but also by environmental factors such as height of patients' bed, the inadequacy of the bed rails, lack of support equipment and unfamiliar environment ${ }^{(20-21)}$. Therefore, it is important to consider environmental issues in both the risk assessment of patients and the strategies for preventing falls.

Problems related to the hospital environment such as high beds and no grids, process failures such as grids that remained lowered and no requests for nursing assistance, were identified in a study that evaluated the risk factors and the incidence of falls in neurosurgical patients in the pre and postoperative periods ${ }^{(22)}$. The identification of environmental hazards such as the following: slippery or uneven floors; low-light places; periodic checking of conditions of beds; latches; wheelchairs; grab bars; in addition to guidance of patients regarding the use of assistive devices for ambulation, allows detecting priority needs and developing strategies for the prevention of accidental falls ${ }^{(23)}$.

It was found that although the nursing care related to environmental safety correspond to the highest numbers of prescriptions, the greatest diversity of prescribed care is mapped in the NIC intervention Fall Prevention, defined as instituting special precautions with patients at risk for injury from falling. Among the 48 different treatments prescribed for patients with ND Risk for falls, 12 were mapped in this intervention, seven targeted the guiding the patients/family and five the assisting and monitoring of ambulation. Besides these, 13 actions of care mapped in other interventions were also included in the intervention I Fall Prevention, showing that it covers a variety of activities related to patients and the environment (intrinsic and extrinsic factors) in the prevention of falls.

Studies indicate that multifactorial interventions (using two or more areas of an intervention, in which every
Nursing care mapping for patients at risk of falls in the Nursing Interventions Classification Luzia MF, Almeida MA, Lucena AF 
patient receives a combination of care according to the risk assessment) ${ }^{(10-11)}$ and multiple interventions (using two or more areas of an intervention for all patients), such as the Fall Prevention, are capable of reducing the occurrence of falls in hospital settings ${ }^{(24-25)}$. Once the event has a character of multiple causes, it requires actions focused on the different risk factors identified in patients.

This idea is corroborated by the results of a study carried out in a university hospital in Japan. A reduction in the rate of falls among hospitalized patients was observed with the use of a multidisciplinary fall prevention program based on interventions such as: risk assessment by instrument, protocol implementation, modifications for environment safety and education of patients/family and staff(25).

The intervention Fall Prevention, according to the NIC includes ten activities related to guidance and education of patients/family. In nursing prescriptions for patients with ND Risk for falls this type of care was also identified, highlighting that 'guiding patients/family regarding the risks and prevention of falls' was the second most frequently prescribed care by nurses. This care is also included in the preventive actions of the Protocol for Prevention of Falls/PNSP, which recommends adopting educational strategies involving patients and family about the risk of falls, and prevention measures at admission and throughout patients' stay in hospital ${ }^{(19)}$.

The other care prescribed by nurses related to orientation/education were: making sure that patients/ family understood the guidance; guiding patients/family; teaching the proper use of crutches, walker, cane and prosthesis; guiding the patients; guiding on ways to adapt to one's limitations and explaining the responsibilities for patients/family.

The guidance of patients and families to understand the presence of risk and fall prevention measures must be a commitment of the healthcare team. Patients need to understand these as really important issues for their safety, because in most times they do not see themselves as vulnerable to the event, and therefore do not adhere to recommendations for prevention ${ }^{(26)}$.

Implementing effective interventions for reducing falls is a challenge due to the complexity of the event. Ideal approaches involve interdisciplinary collaboration, attention to coexisting medical conditions, environmental monitoring and risk reduction, i.e., considering intrinsic and extrinsic factors to patients ${ }^{(4,23-24)}$.

Among these factors, it was found that neurological changes (intrinsic factors to patients) and the nursing activities directed to these conditions constituted the third most prevalent grouping of prescribed care for patients with the ND Risk for falls included in the intervention Neurological monitoring. According to the NIC, this intervention has no connection with the ND Risk for falls, but the literature indicates neurological problems as major risk factors for falls $s^{(1,16,27)}$. In the present study, the prevalence of prescribed care for patients related to the neurological assessment corroborates the literature, and demonstrates that this intervention is important for preventing falls in hospital settings.

The main cognitive functions responsible for balance and posture are attention, orientation, and memory. When limited by neurological changes, they lead to impairments in adaptation to the environment, of judgement, and in the performance of activities that may pose a risk for falls ${ }^{(28)}$. Thus, it is important to carry out a neurological assessment of patients, identify changes related to increased risk for falls, and to establish the most appropriate preventive measures to the condition of each one.

Neurological diseases can cause scenarios of psychomotor agitation and aggressiveness, especially during hospitalization, which lead to the need to install measures that prevent them from causing any damage to themselves and the team ${ }^{(29)}$. One of such measures is the physical restraint, a technique widely used in clinical practice, but also discussed among health professionals and the family, since issues such as the patient's dignity and psychological impact are addressed. Although there is no scientific evidence on the real benefits and risks of this conduct, it is critical to do an accurate assessment of the patient's condition based on clinical judgment, the involvement of the multidisciplinary team and, whenever possible, of the family(30).

In the present study, these issues may be related to the low prevalence of the intervention Physical restraint, which included the nursing care of 'care implementation with mechanical restraint' in 32 prescriptions (3.3\%). The use of physical restraint is done to prevent falls in agitated, semiconscious, unconscious or demented, patients as well as in those addicted or with withdrawal syndrome, and should be performed in a humane manner, according to the recommendations of institutional protocols and legal parameters ${ }^{(31)}$.

Some prescribed nursing care not directly aimed at preventing falls was identified, such as in the intervention Bathing (performing bed bath, hygiene of the scalp, implementing care of facial hair removal and inspecting skin in search for hyperemic or ischemic points), SelfCare Assistance: bathing/hygiene (stimulating hygiene care) and Self-Care Assistance: feeding (assisting in feeding). Such interventions have no direct link with the ND Risk for falls according to the $\mathrm{NIC}^{(9)}$. However, these care may have been prescribed by patients' needs to get help because of their dependence and impaired ability to perform self-care activities, which somehow imply an increased risk for falls. 
Most prescribed care for patients at risk of falls in hospital clinical practice showed consistency with the interventions recommended by the Ministry of Health and ANVISA to reduce the occurrence of falls in hospitals. This includes the implementation of measures that address risk assessment, multidisciplinary care, safe environment and promoting the education of patients and family ${ }^{(19)}$.

\section{CONCLUSION}

The most prevalent nursing care prescribed for patients with ND Risk for falls were: keeping the bed rails, guiding patients/family regarding the risks and prevention of falls, keeping bell within reach of patients and keeping patients' belongings nearby, which were mapped in the interventions Environmental Management: safety and Fall Prevention.

These interventions for the ND Risk for falls included the largest number of prescriptions and diversity of care regarding guiding patients/family, mobilization/ambulation, environmental safety and monitoring of neurological disorders. Thus, these were really a priority for the ND Risk for falls because its activities include the multifactorial as-

\section{REFERENCES}

1. Correa $A D$, Marques $I A B$, Martinez $M C$, Laurino OS, Leão $E R$, Chimentão DMN. The implementation of a hospital's fall management protocol: results of a four-year follow-up. Rev Esc Enferm USP [Internet]. 2012 [cited 2012 Oct 30];46(1): 6774. Available from: http://www.scielo.br/pdf/reeusp/v46n1/ en_v46n1a09.pdf

2. Centers for Disease Control and Prevention; National Center for Injury Prevention and Control. Falls among older adults: an overview [Internet]. Atlanta: CDC; 2011 [cited 2012 Oct 23]. Available from: http://www.cdc.gov/homeandrecreationalsafety/falls/adultfalls.html

3. Abreu C, Mendes A, Monteiro J, Santos FR. Falls in hospital settings: a longitudinal study. Rev Latino Am Enfermagem [Internet]. 2012 [cited 2013 May 17];20(3):597-603. Available from: http://www.scielo.br/pdf/rlae/v20n3/a23v20n3.pdf

4. Vind $A B$, Andersen $H E$, Pedersen $K D$, Joergensen $T$, Schwarz $P$. Effect of a program of multifactorial fall prevention on healthrelated quality of life, functional ability, fear of falling and psychological well-being. A randomized controlled trial. Aging Clin Exp Res. 2010;22(3):249-54.

5. World Health Organization. World Alliance for Patient Safety. Sumary of the evidence on patient safety: implications for research. Geneva; 2008. pect of the event, which is corroborated by the NIC, literature and the national protocol for patient safety and clinical practice. These findings may assist in planning the prevention of falls in hospitals, contributing to a safer nursing care.

The process of cross-mapping between the prescribed care and the NIC interventions for the ND Risk for falls was arduous, since this classification has more than 500 interventions with more than 12,000 activities. Thus, in this process are admitted some limitations relating to the possibility of not having mapped the care of all available NIC interventions. However, the methodological accuracy used ensures that the data presented here include most of them, considering the specific scenario of care to patients with the ND Risk for falls.

The inclusion of the intervention Neurological monitoring is suggested among those recommended to solve/ improve the ND Risk for falls in the chapter of links between the NIC and the NANDA-I. This is due to the fact of this intervention being the third most prevalent group of prescribed care, showing its importance in preventing falls in hospital settings. The intervention Surveillance could also be part of the links as optional additional because it involves activities of monitoring and risk detection.

6. Brasil. Ministério da Saúde. Portaria n. 529, de 10 de abril de 2014. Institui o Programa Nacional de Segurança do Paciente (PNSP) [Internet]. Brasília; 2013 [citado 2014 jun. 9]. Disponível em: http://bvsms.saude.gov.br/bvs/saudelegis/ gm/2013/prt0529_01_04_2013.html

7. Conselho Federal de Enfermagem. Resolução COFEN n॰ 358 de 15 de outubro de 2009. Dispõe sobre a Sistematização da Assistência de Enfermagem e a implementação do Processo de Enfermagem em ambientes públicos ou privados, em que ocorre o cuidado profissional de Enfermagem e dá outras providências [Internet]. Brasília: COFEN; 2009 [citado 2013 maio 17]. Disponível em: http://novo.portalcofen.gov.br/resoluo-cofen-3582009_4384.html

8. NANDA International. Diagnósticos de enfermagem da NANDA: definições e classificação 2012-2014. Porto Alegre: Artmed; 2013.

9. Bulechek GM, Butcher HK, Dochterman JM, Wagner C. Nursing Interventions Classification (NIC). 6th ed. Missouri: Elsevier; 2013.

10. Gillespie LD, Robertson MC, Gillespie WJ, Sherrington C, Gates S, Clemson LM, et al. Interventions for preventing falls in older people living in the community. Cochrane Database Syst Rev. 2012;(9):CD007146.
Nursing care mapping for patients at risk of falls in the Nursing Interventions Classification Luzia MF, Almeida MA, Lucena AF 
11. Cameron ID, Gillespie LD, Robertson MC, Murray GR, Hill KD, Cumming RG, et al. Interventions for preventing falls in older people in care facilities and hospitals. Cochrane Database Syst Rev. 2012;(12):CD005465.

12. McClure R, Turner C, Peel N, Spinks A, Eakin E, Hughes K. Population-based interventions for the prevention of fallrelated injuries in older people. Cochrane Database Syst Rev. 2005;(1):CD004441.

13. Freitas R, Santos SSC, Hammerschmidt KSA, Silva ME, Pelzer MT. Cuidado de enfermagem para prevenção de quedas em idosos: proposta para ação. Rev Bras Enferm [Internet]. 2011 [citado 2013 set. 9];64(3):478-85. Disponível em: http://www.scielo.br/pdf/reben/v64n3/v64n3a11.pdf

14. Shever LL, Titler M, Dochterman J, Fei Q, Picone DM. Patterns of nursing intervention use across 6 days of acute care hospitalization for three older patient populations. Int J Nurs Terminol Classif [Internet]. 2007 [cited 2013 Sept 9];18(1):18-29. Available from: http://www.ncbi.nlm.nih. gov/pubmed/17430534

15. Lightbody E, Watkins C, Leathley M, Sharma A, Lye M. Evaluation of a nurse-led falls prevention programme versus usual care: a randomized controlled trial. Age Ageing [Internet] 2002 [cited 2013 Sept 9]31(3):203-10. Available from: http://ageing.oxfordjournals.org/content/31/3/203.long

16. Costa SGRF, Monteiro DR, Hemesath MP, Almeida MA. Caracterização das quedas do leito sofridas por pacientes internados em um hospital universitário. Rev Gaúcha Enferm [Internet]. 2011 [citado 2012 out. 10];32(4):676-81. Disponível em: http://seer.ufrgs.br/RevistaGauchadeEnfermagem/article/view/18753/14441

17. Moorhead S, Delaney C. Mapping nursing intervention data into the nursing interventions classification (NIC): process and rules. Nurs Diagn. 1997;8(4):137- 44.

18. Lucena AF, Barros ALBL. Mapeamento cruzado: uma alternativa para a análise de dados em enfermagem. Acta Paul Enferm [Internet]. 2005 [citado 2012 out.10];18(1):82-8. Disponível em: http://www.scielo.br/pdf/ape/v18n1/a11v18n1.pdf

19. Brasil. Ministério da Saúde; Agência Nacional de Vigilância Sanitária; Fundação Oswaldo Cruz. Programa Nacional de Segurança do Paciente (PNSP). Anexo 01: Protocolo de Prevenção de Quedas [Internet]. Brasília; 2013 [citado 2014 jun. 9]. Disponível em: http://www.anvisa.gov.br/hotsite/ segurancadopaciente/documentos/julho/Protocolo\%20 -\%20Preven\%C3\%A7\%C3\%A30\%20de\%20Quedas.pdf

20. Dykes PC, Carroll DL, Hurley A, Lipsitz S, Benoit A, Chang F, et al. Fall prevention in acute care hospitals: a randomized trial. JAMA [Internet]. 2010 [cited 2012 Oct 10];304(17):1912-18. Available from: http://www.ncbi.nlm.nih.gov/pmc/articles/ PMC3107709/
21. Vitori AF, Lopes MVO, Araújo TL. Diagnóstico de enfermagem risco de quedas em pacientes com angina instável. Rev RENE [Internet]. 2010 [citado 2012 out. 22];11(1):105-13. Disponível em: http://www.revistarene.ufc.br/vol11n1_html_site/a11v11n1.htm

22. Diccini S, Pinho P, Silva FO. Assessment of risk and incidence of falls in neurosurgical inpatients. Rev Latino Am Enfermagem [Internet]. 2008 [cited 2012 Oct 10];16(4):752-7. Available from: http://www.scielo.br/pdf/rlae/v16n4/16.pdf

23. Almeida RAR, Abreu CCF, Mendes AMOC. Quedas em doentes hospitalizados: contributos para uma prática baseada na prevenção. Rev Enferm Ref [Internet]. 2010 [citado 2013 set. 9];3(2):163-72. Disponível em: http://www.scielo.oces. mctes.pt/pdf/ref/v3n2/v3n2a17.pdf

24. Ang E, Mordiffi SZ, Wong HB. Evaluating the use of a targeted multiple intervention strategy in reducing patient falls in an acute care hospital: a randomized controlled trial. J Adv Nurs. 2011;67(9):1984-92.

25. Ohde S, Terai M, Oizumi A, Takahashi O, Deshpande GA, Takekata $M$, et al. The effectiveness of a multidisciplinary QI activity for accidental fall prevention: staff compliance is critical. BMC Health Serv Res [Internet]. 2012 [cited 2013 Sept 9];12:197. Available from: http://www.ncbi.nlm.nih. gov/pmc/articles/PMC3502440/?tool=pubmed

26. Dykes PC, I-Ching EH, Soukup JR, Chang F, Lipsitz S. A case control study to improve accuracy of an electronic fall prevention toolkit. AMIA Annu Symp Proc [Internet]. 2012 [cited 2013 Sept 3];170-9. Available from: http://www.ncbi. nlm.nih.gov/pmc/articles/PMC3540550/pdf/amia_2012_ symp_0170.pdf

27. Morais HCC, Holanda GF, Oliveira ARS, Costa AG, Ximenes $\mathrm{CMB}$, Araujo TL. Identificação do diagnóstico de enfermagem "risco de quedas" em idosos com acidente vascular cerebral". Rev Gaúcha Enferm [Internet]. 2012 [citado 2012 out.10];33(2):117-24. Disponível em: http://seer.ufrgs.br/ RevistaGauchadeEnfermagem/article/view/20217/19501

28. Ferreira DCO, Yoshitome AY. Prevalência e características das quedas de idosos institucionalizados. Rev Bras Enferm [Internet]. 2010 [citado 2013 set. 3];63(6):991-7. Disponível em: http://www.scielo.br/pdf/reben/v63n6/19.pdf

29. Araújo EM, Martins ES, Adams CE, Coutinho ESF, Huf G. Inquérito sobre o uso de contenção física em um hospital psiquiátrico de grande porte no Rio de Janeiro. J Bras Psiquiatr [Internet]. 2010 [citado 2013 set. 3];59(2):94-8. Disponível em: http://www.scielo.br/pdf/jbpsiq/v59n2/ a03v59n2.pdf 
30. Paes MR, Borba LO, Maftum MA. Contenção física de pessoas com transtorno mental: percepções da equipe de enfermagem. Ciênc Cuid Saúde [Internet]. 2011 [citado 2014 jun. 3];10(2):240-47. Disponível em: http://www.periodicos.uem. br/ojs/index.php/CiencCuidSaude/article/view/9295/pdf
31. Fundação Hospitalar do Estado de Minas Gerais. Protocolos Clínicos. Contenção física de pacientes [Internet]. Belo Horizonte; 2013[citado 2014 jun. 3]. Disponível em: http://www. fhemig.mg.gov.br. 